I. Introducing Maya Polities: Models and Definitions

Damien B. Marken and

James L. Fitzsimmons

2. From the Ground Up: Household Craft

Specialization and Classic Maya Polity Integration

Brigitte Kovacevich

39

3. Negotiated Landscapes: Comparative Regional

Spatial Organization of Tikal and Caracol

Timothy Murtha

4. Political Interaction: A View from the 2,000Year History of the Farming Community of Chan

Cynthia Robin, Andrew Wyatt, James Meierhoff, and Caleb Kestle 99

5. Conceptualizing the Spatial Dimensions of Classic Maya States: Polity and Urbanism at El Perú-Waka, Petén

Damien B. Marken

6. Tomb 68-I, Copan: Deducing Polity Dynamics during the Early Classic Period and Beyond Allan L. Maca

7. La Sufricaya: A Place in Classic Maya Politics

Alexandre Tokovinine and

Francisco Estrada-Belli 
8. The Charismatic Polity: Zapote Bobal and the Birth of Authority at Jaguar Hill

James L. Fitzsimmons

9. Governing Polities: Royal Courts and the

Written Landscape of Late Classic Maya Politics

Sarah E. Jackson

Io. Ideas of City and State: Classic Maya Polities of the Southern Lowlands

James L. Fitzsimmons and

Damien B. Marken

263

List of Contributors

275

Index

279 
Introducing Maya Polities

Models and Definitions

Damien B. Marken and

James L. Fitzsimmons

Problems relating to the size, juxtaposition, and boundedness of social integration in the eastern lowlands remind us that the social scientist must be theoretically and empirically equipped to deal systematically with scale factors. He or she must be able to detect relationships among variables operating at the household level, through the local and regional levels, up to the $250,000 \mathrm{~km}^{2}$ macroregion, and in Mesoamerica as a whole. One must see how actions at one level might accumulate into stresses that are dealt (or not) at the next level. One must be able to specify how many households, over what area, were altered [if at all] because of higher-level changes. (Blanton et al. 198r:178)

For nearly a century, discussions of Classic Maya political organization have been dominated by various forms of the same debate: to what degree were Maya polities centralized or decentralized? The collected authors examine the premises, strengths, and weaknesses of these two perspectives while strongly advocating a move beyond this largely sterile debate. The relatively recent proliferation of archaeological investigation into the functional makeup of preindustrial states and complex polities has increasingly demonstrated the highly dynamic and variable nature of these ancient political and social units (e.g., Bernbeck 2008; Campbell 2009; Glatz 2009; Janusek 2008; Pauketat 200I; Smith 2005). 
Despite the advance in our understanding of Classic Maya political interaction gained by the decipherment of the hieroglyphic record, scholars remain largely unsuccessful in describing and modeling what a Classic Maya polity actually looked like on the ground. This volume is the outgrowth of a roundtable held in the fall of 2009 at Dumbarton Oaks in Washington, DC. Both the roundtable and the volume bring together a group of younger scholars actively investigating Maya political and social structure in the southern lowlands to assess, compare, and interpret the wide variation in Classic period Maya polity and city composition, development, and integration. Focusing on convergences (and divergences) among household, settlement, and epigraphic data in various areas of the Maya world, the chapters in this volume explore several avenues contributing to a more complete comprehension of what constituted Classic Maya political units. Recurring themes discussed range from internal polity identities and organization to polity boundaries and larger extra-polity networks. From this fundamental starting point, the ways political interactions between polities were structured-including their social and historical consequences-can be more accurately studied. Until we better understand how the internal building blocks of polity articulated, interpretations of larger-scale political interaction will remained flawed. The chapters in this volume represent a significant step in that direction.

\section{THEORIZING POLITY}

So how exactly is the term polity to be defined? At its simplest, "polity" can be defined as an autonomous, although not necessarily independent, political unit with some form of a spatially centralized authority structure. In recent years, many social scientists have adopted a similarly broad definition as a more neutral and less loaded alternative to "the state." Few archaeologists would deny guilt at having employed the term polity in conversations of ancient statecraft. We feel, however, that the theoretical concept of polity has more to offer archaeological reconstructions of sociopolitical change than simply an alternate signifier for "the state." More specifically, cross-cultural comparison of a wide variety of political formations can help model a continuum of Classic Maya polity size, form, organization, and history.

In the social sciences, the term polity is originally derived from the Archaic and Classical Greek concept of polis. At times misrepresented as a unilateral equivalent to the Western concept of "city-state," the Greek polis is more accurately described as a specific form, or type, of city-state (see Hansen 2000a). 
Anthropologically defined as a small, self-governing (though again not necessarily independent) state composed of a capital and its surrounding hinterland, the polis has two primary, though overlapping and interrelated, meanings in Classical descriptions of Greek political geography. Mogens Hansen (2006:56) notes that in written sources a polis was simultaneously conceived as a settlement and a community, though both meanings encompassed multiple potential sub-meanings (depending on context). ${ }^{1}$ This duality highlights the fact that the poleis of Archaic and Classical Greece were not simply political communities but the convergence of specific forms of political, religious, economic, and social organization and integration (ibid.:Ir5). As Hansen (ibid.:I46) concludes: "The two most important aspects of the polis were its small size and the unbreakable connection between town and state. With very few possible exceptions, every polis-town with its hinterland was a polis-state, and every polis-state was centered on a polis-town. Most of the other essential features follow from these two characteristics" (emphasis added).

While there are definite similarities (particularly in size) and differences between poleis and Mesoamerican political entities, this idea of the inseparable cognitive link between place and political identification is of particular import to the present discussion (Mann 1993:56; Marcus 1983:206-8; Yaeger 2003; see also Ferguson and Mansbach 1996:87-9I, I44; Oates 1986:24). The duality of meaning Hansen identifies can be taken a step further. Ethnohistoric, archaeological, and epigraphic data from Mesoamerica suggest that emic conceptions of polity in fact encompassed three intertwined aspects of political and social integration and interaction:

I. Polity as a place, a center and its associated hinterlands, with which polity members identified

2. Polity as a community of people that included both urban and rural populations (and did not always make such a distinction)

3. Polity as a political authority (a government).

From this perspective, the fundamental physical and social features of Mesoamerican polities were the capital center, usually housing the residence of the ruler, as well as administrative and religious institutions, and the people and communities that owed political affiliation to that ruler (as well as to each other). In Postclassic Central Mexico, these political and social units manifest as the altepetl and calpolli (depending on size and location; i.e., urban or rural, neighborhood or town) (e.g., Calnek 1976; Hicks 2012; Hirth 2003; Marcus 1983; Smith 2008, 2010:I47, 2011:57-58; Smith and Novic 2012:5-7; York et al. 20Ir:2409). More often than not, these polities were relatively small 
in both physical size and population; Tenochtitlan was actually quite atypical of Aztec cities (Smith 2008:I). Moreover, Tenochtitlan was the capital of an extensive and complex network of variably sized polities bound together by alliance and conquest to form a much larger polity. Although the Aztec period altepetl was a largely self-governing entity, complete external autonomy is not an essential attribute of polity. The degree of autonomy of an individual polity can wax and wane throughout its history (e.g., Hansen 20oob; Yoffee 1988). ${ }^{2}$ This "nesting" of polities at multiple spatial and social scales (Ferguson and Mansbach 1996) is further elaborated below.

Returning to the Maya area, ethnographic research and the available ethnohistories that reference indigenous political organization tend to focus on people and their affiliation to place, not necessarily territory (although some of the ethnohistoric data is conflicting) (e.g., Jones I986, I998; McBryde I947; Okoshi-Harada 2012:293; Roys I957; Tokovinine 2013:I23; Tozzer I941; Vogt I969; see also Campbell 2009; Glatz 2009; Liu and Chen 2003; Smith 2005 for comparative examples). This is not to say that boundaries and control over specific locations and resources were not central concerns, particularly at the local level (e.g., Chase and Chase 1998; Iannone 2006; OkoshiHarada 2012:289; Roys 1957; Scherer and Golden 2009; see also Golden 2010). Ancient rulers were likely well aware of the territorial limits of their political authority; boundaries may have been unmarked, "but an incursion by a rival people beyond the accepted limits was a challenge" both sides would have recognized (Ferguson and Mansbach 1996:83). The point to stress, however, is merely that the modern conceptions of territory that accompany nationstates were largely absent in Mesoamerica until at least the colonial period (see Okoshi-Harada 2012; Smith 2005; Tokovinine 2013).

Turning to the inscriptions, the variable distribution of Emblem Glyphs and toponyms suggests that the Classic Maya did make some distinction between place and political affiliation in terms of personal identification (much like the Greek polis discussed above; see ibid.). This is evidenced by rival dynastic institutions centered at different places and toponymic references to "discrete" areas within the "domain" of specific Emblem Glyphs (Berlin 1958; Stuart and Houston 1994). Nevertheless, however political affiliation was expressed by elites across the lowlands, it seems likely that for many Classic Maya the ideas of city and state were inseparable; capitals did not exist independent of their rural populations, and hinterlands did not function as such without an urban center (or at least a complementary node of sociopolitical interaction). 


\section{SCALE, IDENTITY, AND NETWORKS OF POLITY}

Considering the previous discussion, polities can be of variable size and complexity, not only cross-culturally but within a given region. Polities can range from chiefdoms to localized city-states and regional states to the multiregional empires of the Inka, Vijanagara and Rome. Introducing a recent comparative volume on polity landscapes, Steven Falconer and Charles Redman distinguish between complex polities and state-level authority (Falconer and Redman 2009:4). This separation of polity, as a sociopolitical entity, from state-level authority is more forcibly echoed by Yale Ferguson and Richard Mansbach, who instead emphasize that "a polity has a distinct identity; a capacity to mobilize persons and their resources for political purposes, that is value satisfaction; and a degree of institutionalization and hierarchy" (Ferguson and Mansbach 1996:34). Their extremely broad definition, however, includes kinship and other small-scale social groups, as well as localized community and neighborhood organizations.

Despite the fact that we consider housebold and community - each with a rich body of theory designating its appropriate use - to be better terms at such small spatial scales, anthropological perspectives on household and community organization and integration are nevertheless fully compatible and align with the overlapping and "nested" conception of polities Ferguson and Mansbach describe (see Cohen 1985; de Montmollin 1988, 1989; Hirth 1993; Manzanilla and Chapdelaine 2009; Parkinson 2002; Smith 2010; Wilk and Ashmore I988; Wilk and Netting 1984; Yaeger and Canuto 2000). After all, polities are composed of individuals who are generally recognized as members of a particular household(s), and that household (or its individual members) often shares communal interest(s) or commitment(s) with other households (or individuals) with whom it interacts. Household and community interests and commitments (whether based on kinship, residence, ethnicity, class, gender, religion, politics, or occupation) at times may be at odds with the goals of centralized political authority (or with each other, for that matter). As Ferguson and Mansbach (1996:13) stress: "The state is only one of many collective symbols with which people identify and to which they are loyal. Individuals are subject to crosscutting pressures arising from diverse identities and loyalties. Loyalties to self and extensions of self-family, clan, caste, village, tribe, city, nation, homeland, church, political party, class, and so on-undermine the political capacity of officials and compete with loyalty to the Westphalian polity." ${ }^{3}$ In this sense, the integrated internal and external organization of polities closely resembles Michael Mann's (I986:I6-I7, I993:56) description of societies as everchanging, overlapping and intersecting socio-spatial networks of interaction 


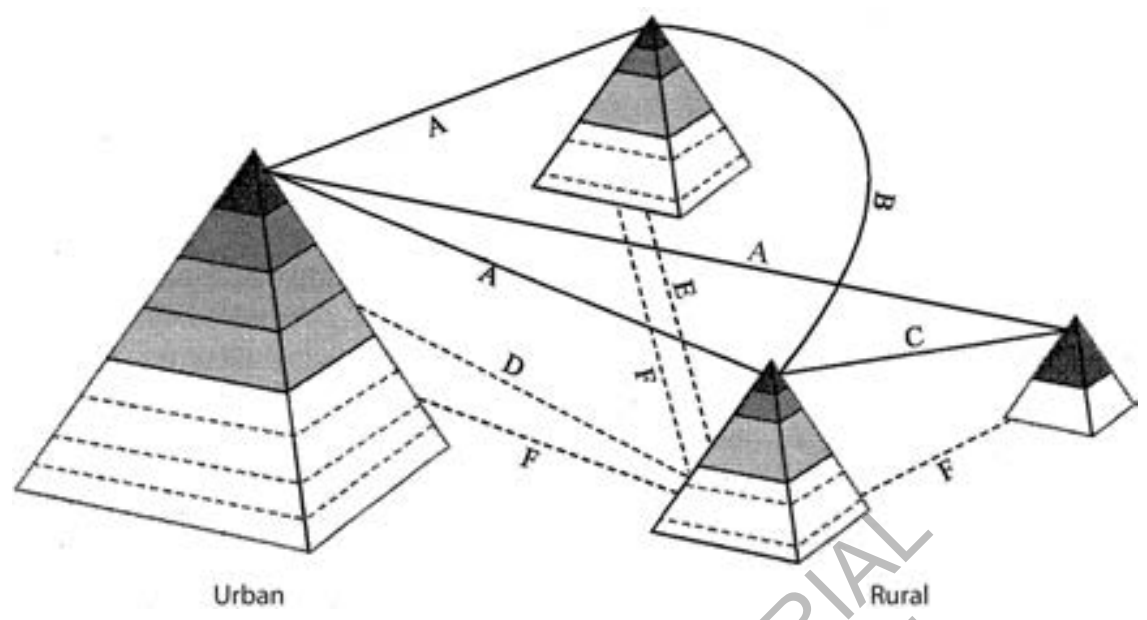

FIGURE I.I. Simplified nested model of internal polity networks, (A) Interactions between urban civic institutions and rural community leaders/institutions; (B) interactions between rural community leadership; (C) relations within rural community leadership; (D) interactions between urban communities and non-civic institutions and rural households; (E) inter-community interactions between rural non-civic groups and institutions and rural households; (F) inter- and intra-community individual household interactions. (Modified from Barnes 2007:figure 2.I)

and power while concurrently placing greater emphasis on the multi-scalar potential of individual and collective identities (Ferguson and Mansbach 1996:32). ${ }^{4}$ Even highly complex polities, such as empires and regional states, were invariably composed of spatially and administratively smaller political units of varying autonomy, as well as less politically defined, but nevertheless socially vital, groups and organizations (figure I.I; e.g., Barth 2000; Cohen 1985; Doyle 1986; Emberling 1997; Smith 2003b; for the Maya, see discussions by Emery and Foias 2012 and LeCount and Yaeger 2orob). Urban and rural communities, gender and kinship networks, class affiliations, ethnic groups, and occupational and religious orders all potentially played critical roles in individual (as well as inter-) polity organization and development.

It is the socio-spatial organization of the networked relationships between the institutions of government and these "components of polity" - as well as the social webs that spawn and link (or separate) these components-that ultimately create, maintain, and negotiate polity identity and polity action through their cooperation, competition, and integration. Polities may have 
been ruled by kings or queens, but they were populated by groups and individuals whose personal traditions, responsibilities, and desires played a fundamental role in shaping their own identity, as well as the decisions of the various socioeconomic networks in which they participated (e.g., Barnes 2007; Yoffee 2005). By viewing Maya polities not as fixed entities but as multiple sets of dynamic and overlapping social, economic, and ideological relationships (Latour 2005), the study of Classic period political organization can avoid many of the pitfalls of static, neo-evolutionary conceptions of the "state" (Campbell 2009:823, 839; Wolf 1990:590). More important, such a network perspective reorients archaeological research to more closely track the varying recursive relationships and power differentials between the groups and institutions that make up polity, along with the multi-scalar study of their articulation and intersection. This is what Edward Schortman and Wendy Ashmore (2012:I) summarize as "the exercise of relational agency by diverse agents operating at multiple, overlapping spatial scales."

\section{RELATIONS OF POWER}

Multi-scalar investigation of preindustrial sociopolitical networks requires a material framework for evaluating interactions between their socio-spatial components, as well as the cultural contexts and meanings of those interactions. The formation of group identities typically includes their juxtaposition against other groups (Insol1 2007). Negotiation or even struggles for power between these groups, with civic and non-governmental institutions, and the power relations that emerge from these interactions are "rooted deep in the social nexus, not reconstituted above' society as a supplementary structure" (Foucault 1983:222). Congruent with recent trends in anthropological archaeology (e.g., Brumfiel r992; Dobres and Robb 2000; Dornan 2002; Knapp and van Dommelen 2008; Pauketat 200I; Saitta 1994), many of the contributors examine the materialization of power and its enactment at or across various spatial scales.

Founded in larger debates in the social sciences surrounding the interplay between agency and structure in constructing and reconfiguring society (e.g., Bourdieu 1977; Giddens 1979, 1984; Latour 2005), power is often defined in archaeology as the variable ability of particular individuals or groups to access and subsequently deploy various social, economic, and ideological resources to achieve specific political goals (e.g., Kockelman 2007; Saitta I994; Wolf I990). In an influential series of publications, Eric Wolf (I990, 1999, 200I) identifies four "modalities" of power: individual, social, tactical/organizational, and 
structural power. Individual power refers to personal attributes that lead to direct interpersonal dominance (Wolf $1990: 586$ ). Social power is the "ability to impose one's will through social interactions" (Ames 2008:488). Wolf's third "mode," tactical or organizational power, is derived from an individual's social or institutional position and operates to direct others within "determinate settings" (Wolf 1990:590), much as a film director controls the actions and performance of his or her actors while lacking final authority over the logistics of "production" (Ames 2008; see also Inomata and Cohen 2006). Organizational power is therefore largely dependent on those groups or individuals within society who control the social configuration of culturally relevant "determinate settings," in other words, those who have structural power (Wolf I990:586).

In traditional and processual assessments of pre-Columbian complex societies, structural power is typically considered implicitly, manifest through the construction and maintenance of monumental works as the domains within which political legitimization was enacted and thus societal authority established (Conlee and Ogburn 2005). Structural power, however, is not simply the authority to organize and direct both the physical and social settings (cf. Rappaport I988; Smith 2003a) that frame the cultural contexts of interaction (whether economic, communal, religious, or political). ${ }^{5}$ It has a second, more dynamic and negotiated facet beyond the oversight of the flows of production (and distribution) of resources (Moore 2005:263). Through control or influence over the organization of particular "social fields" (Lefebvre 199r) or their combination, some groups and individuals potentially gain the ability to (re)define the parameters of social discourse and hierarchy (Wolf I999:5). This constant (re)appropriation and dissemination of cultural expectation and tradition can be highly dynamic and yariably regulated and negotiated through both time and space. While many early theoretical frameworks of preindustrial societal power primarily explored the foundations of stratified power (i.e., the origins of pristine states), the current volume focuses entirely on the organization of power networks at multiple socio-spatial scales within a relatively mature regional cultural tradition (or "city-state culture," as defined by Hansen [2000a, $2000 \mathrm{~b}]$ ) that included rather developed, preexisting conceptions of rulership and political authority.

Several chapters in this volume focus on this internal dynamic of Classic Maya polity. What strategies did rulers employ to incorporate elite and commoner populations into the sociopolitical community in which they served as the political focal point? Were these strategies successful? In what ways did other social groups contest and negotiate their hierarchical relationships with dynasts and among themselves? While some post-roundtable discussions of 
these related issues at Dumbarton Oaks did stray into territory-based definitions and the military/political reach of individual polities, the contributions reveal a focused collective interest in tracing the material remnants of the relational networks of cooperation and conflict among groups, individuals, and institutions that together form the building blocks of polity.

As the authors demonstrate, data from several spatial scales are necessary to cumulatively understand and reconstruct the multifarious ways in which Classic Maya polity could be negotiated and materialized. Moreover, a better understanding of the internal components of polity—and their relationships to each other-offers important social context to the study of inter-polity interactions (Fash and Sharer 199I). Such attention to the material correlates of the dynamics of social difference and interaction has a long history in Maya archaeology, and multi-scalar analyses already form a prominent aspect of recent conceptions of Classic period political organization (e.g., Arnauld 2008; Arnauld et al. 2012; Chase 1992; Chase and Chase 1992; Coe 1959; Culbert 1973, I991; Foias and Emery 20I2a; Gifford 1976; Hendon 1991, 2009; Inomata 200I; LeCount and Yaeger 2010a; Lemonnier 2012; Marken and Straight 2007; Sabloff 1986, 1994; Robin, Yaeger, and Ashmore 2oro; Schortman 1989; Sharer I988, I993; Smith and Novic 20I2; Willey and Leventhal 1979; Willey et al. 1965). Though a subtle conceptual shift, network models of polity structure foster the generation of new questions regarding how Classic polities operated, as well as provide flexible, data-driven frameworks for their systematic investigation (e.g., Munson and Macri 2009; Schortman and Ashmore 2012; Schortman and Urban 2012; see also Campbell 2009).

\section{CLASSIC MAYA POLITIES: DOMINANT INTERPRETATIONS}

Several large and secondary Maya centers, often characterized by the presence of carved hieroglyphic monuments, have been investigated. However, research on the settlements that encircle these centers-sites comprising the lower rungs of an assumed settlement hierarchy-has generally been less intensive. Studies of peripheral and inter-site settlement, as well as the growing body of information on "commoner" households, demonstrate that highly diverse, dynamic, yet intertwined systems of interaction and integration were in place at multiple scales during the Classic period (e.g., Bullard I96o; Canuto 2002, 2004; Fialko Coxemans 1996; Ford 1986; Hendon I991, 20I0; Houston et al. 2003; Hutson 20Io; Iannone and Connell 2003; LeCount and Yaeger 2orob; Lohse and Valdez 2004; Marken 2oIr; Puleston 1983; Robin 1999, 2003, 2006, 20I2; Webster and Gonlin 1988; Willey et al. 1965; Yaeger 2000a, 2000b, 2003). 
This is not to say that particular Maya polity capitals did not at times exert various forms of hegemonic control over non-local areas during their histories (e.g., Martin and Grube 2000). However, the full extent and range of the consequences-economic, social, or political —of such interactions have proven difficult to track materially (Hammond 1991; Marken and Straight 2007; Sharer and Traxler 2006). Aside from a few select cases, Mayanists have been unable to define not only the boundaries but indeed the full settlement composition of most Classic polities (e.g., Ashmore r98r; Ashmore, Yaeger, and Robin 2004; Chase and Chase 1987, 1994; Demarest 2006; Fialko Coxemans 1996; Folan 1992; Folan, Kintz, and Fletcher 1983; LeCount and Yaeger 20Ioa; LeCount et al. 2002; Liendo Stuardo 2003, 20II; Robin 2002; Scarborough, Valdez, and Dunning 2003; Willey et al. 1965; Willey et al. 1975). Two of the most intensively investigated Maya sites-Copan, Honduras, and Tikal, Guatemala—stand out as exceptions. Both sites have a well-preserved hieroglyphic corpus and have been the focus of multiple long-term investigations, resulting in a detailed archaeological and historical record of the development of not only both centers but their surrounding hinterlands as well (e.g., Andrews, Wyllys, and Fash 2005; Bell, Canuto, and Sharer 2004; Fash 200I; Harrison 2000; Sabloff 2003).

\section{COPAN, HONDURAS: THE MAYA CASE STUDY}

On the southeastern periphery of the Maya world, Copan and its surrounding region is easily the best-studied, in terms of both quantity and quality of investigation, archaeological site in the Maya area. Moreover, the region lacks the dense vegetation characterizing most of the Maya lowlands; high settlement visibility has encouraged extensive regional surveys of Copan's immediate vicinity, as well as adjacent valleys (e.g., Canuto 2002, 2004; Fash and Long 1983; Freter 1988; Willey and Leventhal 1979). Broadly speaking, the Late Classic Copan polity core can be defined by a set of stelae arranged around the border of a natural physical boundary (the Copan Valley) (Fash 200I, 2005; Fash and Long 1983; Fash and Stuart 199I). Valley-wide surveys indicate that Late Classic elite groups often occupied, or were adjacent to, the best agricultural lands in the valley (Webster 2005). These groups also tend to have been settled earlier than lower-status groups, suggesting that the initial basis for social differentiation in the valley was tied to differential access to agricultural resources (ibid.). In this reconstruction, this agricultural surplus was eventually converted by certain groups into elevated social status and political authority, most notably by the inhabitants of what would become Copan's ceremonial 
center (Fash 2005; Hall and Viel 2004). This process ultimately resulted in a settlement pattern characterized by a highly nucleated urban center and several large elite residential groups dispersed among numerous lower-ranked settlements throughout the valley (Fash 1983; Willey and Leventhal 1979).

Such simple neo-evolutionary models, however, overlook local history and urban-rural relationships (Canuto and Fash 2004; Fash and Fash 2005). Moreover, Copan may not be an ideal example from which to generalize about Classic Maya political and social structure. As a "river center" (Lucero 2006) on the periphery of the Maya world, mechanisms of interaction, control, and the legitimization of authority at Copan likely coalesced differently than in the Maya heartland, where centers of comparable size were more numerous and closely packed. Furthermore, Maya leaders in the region also interacted more intensely with non-Maya populations (Canuto and Fash 2004; Hendon 2009; Inomata and Aoyama 1996; Schortman, Urban, and Ausec 200I). These sorts of interactions likely presented alternate social and political challenges and opportunities for both elite and non-elite groups.

\section{TIKAL, GUATEMALA: THE MAYA "MEGA-SITE"}

Compared with many sites in the central lowlands, investigations at Tikal have intensively focused on issues of site boundaries and settlement diversity within Maya polities (e.g., Becker 1999; Culbert et al. 1990; Fry 1969, 2003; Haviland I963, I970, 1985, 2003; Orrego Corzo and Larios 1983; Puleston 1973, I983; Webster et al. 2007; see Murtha, chapter 3, this volume). Nevertheless, the dense lowland vegetation has severely limited survey sampling strategies. An approximately $120-\mathrm{km}^{2}$ polity core has been estimated by a combination of three features (Culbert et al. 1990:Ir5): (I) a drop-off in structure density away from the center; (2) an extensive series of earthworks, whose exact function(s) remains unknown, to the north and south of the epicenter; and (3) impassible bajo areas to the east and west (Ford 1986; Fry 1969, 2003; Puleston 1983; Puleston and Callender 1967; Webster et al. 2004; Webster et al. 2007). Transect and block surveys, conducted by multiple independent long-term projects, have mapped approximately $5 \mathrm{I} \mathrm{km}^{2}$ of this area since the late $1950 \mathrm{O}$ (Carr and Hazard I96r; Ford 1986; Puleston 1973, I983; Webster et al. 2007:50).

The massive amount of survey and excavation data from Tikal and other projects explicitly investigating the spatial limits and structure of Maya polities indicates that Classic centers were highly variable and dynamic locations on the landscape (e.g., Bullard 1960; Chase and Chase 1994; Culbert et al. I990; Demarest 2006; Folan 1992; Kurjack 1974; Laporte and Mejía 2005; LeCount 
and Yaeger 2010b; Marcus 1993, 1998; Nelson 2005; Tourtellot 1988; Webster et al. 2007; Willey and Bullard 1965; Willey et al. 1965). Moreover, analyses of ceramic and architectural data have demonstrated diverse social and economic differences and connections between central elites and peripheral populations (e.g., Ashmore, Yaeger, and Robin 2004; Demarest 2006; Foias 1996; Foias et al. 20I2; Fry 1969; Haviland I98r; Robin I999; Straight 20I2; Yaeger 2000a).

\section{CENTRALIZED OR DECENTRALIZED?}

However, the data from Tikal and Copan have fueled a prolonged debate over the degree to which Classic Maya political units were centralized or decentralized. Over the years, this debate has manifested itself in several ways, including discussions of Maya urbanism, unitary versus segmentary states, and sociopolitical complexity (e.g., Barnhart 2007; Chase and Chase 1996; Chase, Chase, and Haviland 1989; Demarest 1992; Fox et al. 1996; Haviland 1970; Iannone 2002; Marcus 2004; Sanders and Price 1968; Sanders and Webster I988; Sharer and Golden 2004; Webster and Sanders 200I). ${ }^{6}$ Unfortunately, these debates have had a polarizing effect within the discipline; perspectives often correlate with the kinds of data researchers gather or choose to prioritize (Canuto and Fash 2004; Foias and Emery 20I2b). Interpretations overly reliant on data from elite contexts, even when informed by settlement data from a limited number of centers, mask the very real variability in material culture, demographic trends, and political history across the Maya lowlands. Increased attention to integrating variation in regional settlement and household dynamics with monumental construction and epigraphic cultural history across the lowlands within a multi-scalar and networked polity perspective is a potential remedy to this intra-disciplinary factionalism (Schortman and Ashmore 20I2).

The decentralized and centralized models of Maya polities are generally placed in opposition to each other (Fox et al. 1996). In fact, they reflect conceptualizations of the Classic period political landscape at different scales of analysis. Although largely derived from ethnohistoric evidence, the material correlates given for decentralized models usefully describe Classic Maya polities at the pan-regional level, especially when integrated within a peer-polity framework (e.g., Iannone 2002:69; Marken and Straight 2007; Renfrew I986; Sabloff 1986). Larger Maya capitals do exhibit some functional redundancy, as well as highly fluctuating and unstable long-term political integration between one another (Demarest 1992; Hammond 1991). On the other hand, the material expectations of centralized political models highlight extreme ideological, 
economic, and political integration within Classic Maya polities, where secondary and tertiary sites and hamlets exhibit specialized functional qualities within local polity hierarchies (e.g., Chase and Chase 1996:805; Emery and Foias 20I2; Iannone 2002:70; Scarborough and Valdez 2003).

The principal drawback of the decentralized-centralized debate is that the material expectations of each model are not mutually exclusive. Rather than emphasize either-or conceptions of Classic sociopolitical structure, it is better to assume that organization within and between Maya polities was multifaceted and variable in both space and time. The fact that a clear class distinction existed between elites and commoners, evident from several lines of evidence (following centralists), does not preclude the importance of kin- or residencybased relationships in organizing, negotiating, and legitimizing authority structures for both elites and commoners (following decentralists). It should be no surprise that multiple (and potentially independent or competing) horizontal and vertical organizational and integration mechanisms were functioning concurrently (Crumley 1995; Foias and Emery 2012b; Kantner 2008; LeCount and Yaeger 20Iob; Pyburn 2008; Schortman I989; Smith 20II; Stein 2002; Willey and Bullard 1965; Yaeger and Canuto 2000). A focus on modeling the relationships between local populations and central elites at the household, community, urban-rural, and polity levels, as well as their distribution across the natural landscape, would allow for more comprehensive interpretations of the internal constitution of Classic polities. Improved understanding of these sorts of relationships would, in turn, provide critical contexts for reconstructing the meanings and consequences of inter-polity interactions.

\section{THE DYNAMICS OF POLITY IN THE CLASSIC MAYA WORLD}

The complexity of lowland sociopolitical networks and landscapes demands massive quantities of systematic data collection and analysis from a range of social, spatial, and temporal contexts for a truly comprehensive synthesis. Such mature data sets are rarely possible (in terms of time and funding) in the current climate of archaeological investigation. The chapters in this volume therefore naturally focus on specific aspects of Classic Maya polity. To best capture the variation seen across the lowlands, contributions emphasize distinct combinations of different analytical units and interaction scales.

The volume begins with several contributions that examine the roles and impacts of household decision-making on larger political structures. In recent decades, household excavations across Mesoamerica have significantly increased in number, spatial expanse, and analytical intensity (Carballo 20II; 
Robin 2003; e.g., Halperin and Foias 2010; Healan 2009; Hendon 1991; Hirth 2009; Inomata and Triadan 2oro; Manzanilla 2009; Marken and González Cruz 2007; Palka 1997; Plunket 2002; Santley and Hirth 1993). These studies demonstrate that elite and non-elite households were active participants in the negotiation of polity.

In chapter 2, Kovacevich builds upon these earlier studies to further explore how changes at the household level inform the internal relationships of polity. Through examination of jade craft production at Cancuen, Guatemala, she explores alternate power strategies available to elites in reinforcing Late Classic social hierarchies. Although the restriction of the final stages of jade artifact manufacture to elite households reinforced their elevated status, the early-stage participation of non-elite artisans in jade production concurrently conferred upon these households new social identities and status.

Over the course of chapter 3 , Murtha argues that we need to disabuse ourselves of the notion that Classic Maya rulers wielded strong, centralized economic control over their subjects. As he outlines, results from the long-term research programs at Caracol, Belize, and Tikal, Guatemala, are often used to create models of strong, centralized Maya polities. Comparing their physical, settlement, and agricultural landscapes, he identifies broad patterns in the ways households and agricultural production may have been integrated into regional political systems. He likewise notes a difference between the settlement patterns of the two sites - the households at Caracol are evenly dispersed, for example, whereas at Tikal they are distributed in more fragmented clusters-and suggests that contrasts like these can be attributed not only to differences in local environments but also to variations in agricultural organization. This perspective focuses on the local features attractive to individuals in explaining household agglomeration and dispersal, suggesting a more complex, fluid, and dynamic regional landscape than implied by binary models of political structure.

The subsequent chapter, by Robin and her colleagues, continues to explore the role of households in Maya polity, in this case at the small "minor center" (Bullard 1960) of Chan in the Belize Valley. A farming community in the hinterlands of the Late Classic center of Xunantunich, Chan's 2,000-year occupation provides a unique diachronic perspective on intra-polity integration and political negotiation. In their attempt to insert commoners as active participants in polity, the authors examine how an established farming community was potentially affected by its interaction with a polity capital and how a nascent polity capital would have had to tailor its strategies to existing communal relationships. They do so by focusing on the long-term development 
of terraced agriculture and the diachronic variation in local and exotic craft production by Chan farming households. Their research shows that hinterland households and communities were neither fully autonomous nor entirely dependent upon capital elites and institutions; commoner contributions to broader regional political dynamics were much more complex than allowed by either centralized or decentralized models.

The recursive nature of urban-rural integration is further discussed by Marken in chapter 5. Building upon and refining earlier spatial models of Maya polity through a detailed settlement study at El Perú-Waka', Guatemala, he outlines a framework linking conceptions of Classic Maya urbanism and polity. Although he is able to identify three distinct etic settlement zones at El Perú-Waka - (I) an urban core, (2) a near periphery, and (3) a far peripheryMarken argues that all three zones were fundamental to the operation and conceptualization of polity. By embracing emic definitions that blur spatial distinctions between city and polity (e.g., Marcus 1983), Marken presents Classic Maya polities as functionally integrated urban-rural communities, a stance supported by evidence of widespread low-level rural craft production and the potential influence of urban elites on rural ritual spaces.

Chapters 6 through 9 shift attention away fromarguments involving the integration-or lack thereof-between rural and urban settlements toward dynastic politics and political structures. In chapter 6 Maca builds on his previous arguments (Maca 2006) and those by Plank (2004) to examine Late Classic dynastic attempts to maintain control over outlying communities within the Copan Valley through the construction of monumental elite compounds. In particular, four late Late Classic "U-Groups" built outside the Principle Group replicate the form of Copan's Great Plaza and reference the quadripartite urban planning of the thirteenth ruler, Waxaklahun Ubah K'awil, better known as I8-Rabbit (Maca 2002). Though rooted in a detailed reconstruction of settlement history, Maca's narrative focuses on describing the social context of Tomb 68-I, discovered by his team within a U-Group in the E1 Bosque district of the city. The only monumental tomb recorded outside the Acropolis at Copan, Tomb 68-I is a remarkable find; Maca has identified three additional burials with similar "string-line" pectorals dating to the 6th century $\mathrm{CE}$, all located within or near the three other U-Groups located outside the Principle Group. He argues that these four 6th-century string-line pectoral burials were important physical markers of urban planning during the reign of I8-Rabbit. Copan's final dynast, Yax Pasaj, tapped into that heritage in building U-Groups atop or near these earlier burials. Maca's study highlights that Copan was a multi-ethnic community whose 
particular culture history played a significant role in its organizational development. Yax Pasaj's attempt to sustain his polity ultimately failed, but his effort is a reminder that even at the end of the Classic period, Maya rulers still wielded considerable authority.

The chapter by Tokovinine and Estrada-Belli examines the role of Classic Maya courts in larger political processes. Reviewing the chronological and epigraphic history of the palace complex at La Sufricaya, Guatemala, the authors reconstruct changing narratives of community and place at this small center. Their attention to the conjunction of local and regional history with the rearrangement and recreation of space at La Sufricaya highlights the potentially recursive nature of internal and external forces on the formulation of Classic Maya polities at the urban scale.

The final two case studies expand the analytical scale of polity to that of the region. The first of these takes a theoretical approach: Fitzsimmons argues that territorial boundaries are largely dependent upon authority and perceptions of authority, whether they have their basis in law, tradition, or personal charisma. Taking a top-down approach to galactic models of political territoriality (Demarest 1992; Tambiah 1977), Fitzsimmons evaluates their fit with Maya examples in the Hiix Witz polity of the western Petén, Guatemala, south of the Rio San Pedro Martir. While recognizing the strengths of galactic models, Fitzsimmons nevertheless suggests that these types of models attribute a passive role to kingship that conflicts with the need of Classic Maya rulers to actively accrue power and authority through success in ritual, warfare, and other forms of sociopolitical interaction. Examining the archaeological data from Hiix Witz, characterized by a series of small centers with inscriptions, he makes a strong case for conceiving of Classic Maya political units as "charismatic polities," whose authority and territoriality were asserted through the actions of their rulers. Moreover, while the development of additional sources of authority could be highly variable, these sources were ultimately outgrowths of charismatic authority and were reinforced by the exertion of power.

Many analyses of Classic Maya polities that rely on hieroglyphic inscriptions concentrate on local site histories and regional-scale interactions (e.g., Martin and Grube 2000). The second case study takes a different approach: in chapter 9, Jackson systematically tracks the spatial and temporal distribution of sub-royal (e.g., petty elite) titles during the Classic period as a way of understanding the different echelons of internal polity political structure. Although admittedly limited in sociopolitical scope, the inscriptions provide a unique emic perspective on the internal organization of Classic period royal 
courts. In her examination of the offices within Maya courts, Jackson is able to identify a common governmental framework across the lowlands. In practice, however, the different offices seem to have held variable importance between sites and regions.

\section{FINAL THOUGHTS}

Archaeological and epigraphic data indicate that multiple forms of interaction occurred between Classic Maya centers. However, if conceptions of Maya polities remain focused on Tikal, one of the largest and longest-occupied Classic period sites, as well as on Copan on the southeast periphery, more detailed understanding of the relationships between large "primary" centers and potentially subordinate centers within the Maya heartland will remain obscure. Of interest is not only how "secondary" centers interacted with larger centers such as Tikal but how these smaller centers incorporated their own local populations into larger interaction spheres. With a better handle on variations between these Maya centers, interpretations of elite-level interactions recorded in the inscriptions can be better understood in their social, political, and historical contexts. By comparing multiple spatial data sets from the southern lowlands, this volume evaluates the potential variability in internal Maya polity organization across the Classic period social landscape. It also, it is hoped, lays the foundation for more nuanced and historically balanced interpretations and research on the organization of - and variation betweenClassic Maya polities.

\section{NOTES}

I. As a settlement, polis designated a nucleated, or urban, locale, that is, a town or city, but also occasionally referenced a defined territory; as a community, polis referred to an institutionalized political society, that is, a state, encompassing the overlapping meanings of a male citizenry, a city assembly, or a more abstract "imagined" community (Hansen 2006:56-57).

2. This "waxing" and "waning" of autonomy should not be confused with Joyce Marcus's (1993, 1998) Dynamic Model of regional cycles of political centralization and fragmentation.

3. The term Westphalian polity or state refers to the 1648 Peace of Westphalia within which the term territorial state was coined. In the social sciences, the term is often employed as an equivalent to the nation-states that developed in seventeenthcentury Europe and their successors. 
4. Ferguson and Mansbach (1996:32), however, feel that "Mann overemphasizes the supposed 'autonomous power of the state' at the expense of attitudes and especially identities" (see Campbell [2009:824] for a similar critique).

5. These potentially overlapping or crosscutting "domains" of culture (i.e., economy, identity/ethnicity, ideology, religion, politics) can be variably congruent or in conflict at different spatial or social scales.

6. The current discussion centers on the decentralized/centralized dichotomy as it tends to place greater emphasis on the material correlates of political complexity, specifically the features of individual polities. Time and space constraints therefore force several alternative models of Maya political structure to be largely skipped in this introduction. Examples include the galactic polity model (Demarest 1992), the super-state model (Martin and Grube 1995), and the court-centric model (Inomata and Houston 200I). However, excellent reviews of these particular conceptual models are available elsewhere (e.g., Chase and Chase i998; Prem 1998).

\section{REFERENCES}

Ames, Kenneth M. 2008. “The Archaeology of Rank.” In Handbook of Archaeological Theories, edited by R. Alexander Bentley, Herbert D.G.Maschner, and Christopher Chippindale, 487-513. New York: AltaMira.

Andrews, E., V. Wyllys, and L. William Fash,eds. 2005. Copán: Rise and Fall of a Classic Maya Kingdom. Santa Fe: School of American Research Press.

Arnauld, M. Charlotte. 2008. "Maya Urbanization: Agrarian Cities in a Preindustrial World.” In Urbanism in Mesoamerican, vol. 2, edited by Alba Guadalupe Mastache, Robert H. Cobean, Ángel García Cook, and Kenneth G. Hirth, I-36. Mexico City: Instituto Nacional de Antropologia e Historia.

Arnauld, M. Charlotte, Dominique Michelet, Boris Vannière, Philippe Nondédéo, and Eva Lemonnier. 2012. "Houses, Emulation, and Cooperation among the Río Bec Groups." In The Neighborhood as a Social and Spatial Unit in Mesoamerican Cities, edited by M. Charlotte Arnauld, Linda R. Manzanilla, and Michael E. Smith, 202-28. Tucson: University of Arizona Press.

Ashmore, Wendy. 198r. "Some Issues of Method and Theory in Lowland Maya Settlement Archaeology.” In Lowland Maya Settlement Patterns, edited by Wendy Ashmore, 37-69. School of American Research Advanced Seminar Series. Albuquerque: University of New Mexico Press.

Ashmore, Wendy, Jason Yaeger, and Cynthia Robin. 2004. "Commoner Sense: Late and Terminal Classic Social Strategies in the Xunantunich Area." In The Terminal Classic in the Maya Lowlands, edited by Arthur A. Demarest, Prudence M. Rice, and Don S. Rice, 302-23. Boulder: University Press of Colorado. 
Barnes, Gina L. 2007. State Formation in Japan: Emergence of a 4 th-Century Ruling Elite. London: Routledge.

Barnhart, Edwin. 2007. "Indicators of Urbanism at Palenque." In Palenque: Recent Investigations at the Classic Maya Center, edited by Damien B. Marken, Io7-2I. New York: AltaMira.

Barth, Fredrik. 2000. "Boundaries and Connections." In Signifying Identities, edited by Anthony P. Cohen, 17-36. London: Routledge.

Becker, Marshall J. I999. Excavations in Residential Areas of Tikal: Groups with Shrines: Tikal Report 2I. Philadelphia: University Museum, University of Pennsylvania.

Bell, Ellen E., Marcello A. Canuto, and Robert J. Sharer, eds. 2004. Understanding Early Classic Copan. Philadelphia: University of Pennsylvania Press.

Berlin, Heinrich. 1958. "E1 glifo emblema en las inscripciones mayas." Journal de la Société des Americanistes 47 (I): III-I9. http://dx.doi.org/IO.3406/jsa.I958.II53.

Bernbeck, Reinhard. 2008. "The Rise of the State.” In Handbook of Archaeological Theories, edited by R. Alexander Bentley, Herbert D.G. Maschner, and Christopher Chippindale, 533-45. New York: AltaMira.

Blanton, Richard E., Stephen A. Kowalewski, Gary M. Feinman, and Jill Appel. 1981. Ancient Mesoamerica: A Comparison of Change in Three Regions. Cambridge: Cambridge University Press.

Bourdieu, Pierre. 1977. Outline of a Theory of Practice. Cambridge: University of Cambridge Press. http://dx.doi.org/10.Ior7/CBO97805118I2507.

Brumfiel, Elizabeth M. 1992. "Distinguished Lecture in Archaeology: Breaking and Entering the Ecosystem: Gender, Class, and Faction Steal the Show." American Anthropologist 94 (3): 55I-67. http://dx.doi.org/Io.I525/aa.I992.94.3.02a00020.

Bullard, William R, Jr. 1960. "Maya Settlement Patterns in Northeastern Peten, Guatemala." American Antiquity 25 (3): 355-72. http://dx.doi.org/10.2307/277519.

Calnek, Edward E. 1976. “The Internal Structure of Tenochtitlan.” In The Valley of Mexico, ed. Eric R. Wolf, 287-302. Albuquerque: University of New Mexico Press.

Campbell, Roderick B. 2009. "Towards a Networks and Boundaries Approach to Early Complex Societies.” Current Anthropology 50 (6): 82I-48. http://dx.doi.org /Io.Io86/648398.

Canuto, Marcello A. 2002. "A Tale of Two Communities: Social and Political Transformation in the Hinterlands of the Maya Polity of Copán.” PhD dissertation, University of Pennsylvania, Philadelphia.

Canuto, Marcello A. 2004. "Rural Settlement of Copan: Changes through the Early Classic.” In Understanding Early Classic Copan, edited by Ellen E. Bell, Marcello A. Canuto, and Robert J. Sharer, 29-50. Philadelphia: University of Pennsylvania Press. 
Canuto, Marcello A., and William L. Fash. 2004. "The Blind Spot: Where the Elite and Non-Elite Meet." In Continuities and Changes in Maya Archaeology: Perspectives at the Millennium, edited by Charles W. Golden and Greg Borgstede, 51-75. New York: Routledge.

Carballo, David M. 2orI. "Advances in the Household Archaeology of Highland Mesoamerica." Journal of Archaeological Research ig (2): 133-89. http://dx.doi.org /IO.IO07/sio8I4-OIO-9045-7.

Carr, Robert F., and James E. Hazard. 196r. Map of the Ruins of Tikal, El Peten, Guatemala. Tikal Report II, University Museum Monograph 2r. Philadelphia: University of Pennsylvania.

Chase, Arlen F. 1992. "Elites and the Changing Organization of Classic Maya Society.” In Mesoamerican Elites: An Archaeological Assessment, edited by Diane Z. Chase and Arlen F. Chase, 30-49. Norman: University of Oklahoma Press.

Chase, Arlen F., and Diane Z. Chase. 1987. Investigations at the Classic Maya Center of Caracol, Belize: 1985-1987. Monograph 3. San Francisco: Pre-Columbian Art Research Institute.

Chase, Arlen F., and Diane Z. Chase. 1992. "Mesoamerican Elites: Assumptions, Definitions, and Models." In Mesoamerican Elites: An Archaeological Assessment, edited by Diane Z. Chase and Arlen F. Chase, 3-17. Norman: University of Oklahoma Press.

Chase, Arlen F., and Diane Z. Chase. r996. "More than Kin and King: Centralized Political Organization among the Late Classic Maya." Current Anthropology 37 (5): 803-3o. http://dx.doi.org/I0.1086/204564.

Chase, Arlen F., and Diane Z. Chase. I998. "Late Classic Maya Political Structure, Polity Size and Warfare Arenas." In Anatomía de Una Civilización, edited by Andrés Cuidad Ruiz, II-29. Madrid: Sociedad Española de Estudios Mayas.

Chase, Diane Z., and Arlen F. Chase, eds. I994. Studies in the Archaeology of Caracol, Belize. Monograph 7. San Francisco: Pre-Columbian Art Research Institute.

Chase, Diane Z., Arlen F. Chase, and William A. Haviland. I989. "The Mesoamerican Urban Tradition: A Reconsideration." American Anthropologist 9I (3): 499-506.

Coe, William R. 1959. Piedras Negras Archaeology: Artifacts, Caches, and Burials. Philadelphia: University Museum, University of Pennsylvania.

Cohen, Anthony P. 1985. The Symbolic Construction of Community. London: Routledge. http://dx.doi.org/I0.4324/9780203323373.

Conlee, Christina A., and Dennis Ogburn. 2005. "Foundation of Power in the Prehispanic Andes." In Foundations of Power in the Prehispanic Andes, edited by Kevin J. Vaughn, Dennis Ogburn, and Christina A. Conlee, I-I2. Archaeological Papers I4. Arlington, VA: American Anthropological Association. 
Crumley, Carole L. 1995. "Heterarchy and the Analysis of Complex Societies." In Heterarchy and the Analysis of Complex Societies, edited by Robert M. Ehrenreich, Carole L. Crumley, and Janet E. Levy, I-5. Archaeological Papers 6. Arlington, VA: American Anthropological Association. http://dx.doi.org/Io.1525/ap3a.I995.6.I.I.

Culbert, T. Patrick, ed. 1973. The Classic Maya Collapse. Albuquerque: University of New Mexico Press.

Culbert, T. Patrick, ed. I99I. Classic Maya Political History: Hieroglyphic and Archaeological Evidence. Cambridge: Cambridge University Press.

Culbert, T. Patrick, Laura J. Kosakowsky, Robert E. Fry, and William A. Haviland. 1990. "The Population of Tikal, Guatemala." In Precolumbian Population History in the Maya Lowlands, edited by T. Patrick Culbert and Don S. Rice, I03-2I. Albuquerque: University of New Mexico Press.

de Montmollin, Olivier. 1988. "Scales of Settlement Study for Complex Societies: Analytical Issues from the Classic Maya Area." Journal of Field Archaeology I5 (2): I5I-68. http://dx.doi.org/Io.II79/oo9346988791974529.

de Montmollin, Olivier. 1989. The Archaeology of Political Structure: Settlement Analysis in a Classic Maya Polity. Cambridge: Cambridge University Press. http://dx.doi .org/ıo.ıoi7/CBO9780511659867.

Demarest, Arthur A. 1992. "Ideology in Ancient Maya Cultural Evolution: The Dynamics of Galactic Polities." In Ideology and Pre-Columbian Civilizations, edited by Arthur A. Demarest and Geoffrey W. Conrad, I35-57. Santa Fe: School of American Research Press.

Demarest, Arthur A. 2006. The Petexbatun Regional Archaeological Project: $A$ Multidisciplinary Study of the Maya Collapse. Nashville: Vanderbilt University Press.

Dobres, Marcia-Anne, and John Robb, eds. 2000. Agency in Archaeology. London: Routledge.

Dornan, Jennifer. 2002. "Agency in Archaeology: Past, Present, and Future Directions." Journal of Archaeological Method and Theory 9 (4):303-29. http://dx.doi .org/IO.IO23/A:IO21318432I6I.

Doyle, Michael W. I986. Empires. Ithaca, NY: Cornell University Press.

Emberling, Geoff. 1997. "Ethnicity in Complex Societies: Archaeological Perspectives." Journal of Archaeological Research 5 (4): 295-344. http://dx.doi.org/ro .1007/BF02229256.

Emery, Kitty F., and Antonia E. Foias. 20I2. "Landscape, Economies, and the Politics of Power in the Motul de San José Polity." In Motul de San José: Politics, History, and Economy in a Classic Maya Polity, edited by Antonia E. Foias and Kitty E. Emery, 4OI-I8. Gainesville: University Press of Florida. http://dx.doi.org/Io.5744 /florida/97808I304I902.003.00I5. 
Falconer, Steven E., and Charles L. Redman. 2009. “The Archaeology of Early States and Their Landscapes." In Polities and Power, edited by Steven E. Falconer and Charles L. Redman, I-Io. Tucson: University of Arizona Press.

Fash, William L. I983. "Deducing Social Organization from Classic Maya Settlement Pattern: A Case Study from the Copan Valley." In Civilization in the Ancient Americas, edited by Richard M. Leventhal and Alan L. Kolata, 26I-88. Albuquerque: University of New Mexico Press and Peabody Museum of Archaeology and Ethnography.

Fash, William L. 20or. Scribes, Warriors and Kings: The City of Copan and the Ancient Maya. London: Thames and Hudson.

Fash, William L. 2005. “Toward a Social History of the Copán Valley.” In Copán: Rise and Fall of a Classic Maya Kingdom, edited by E. Wyllys Andrews V and William L. Fash, 73-Ior. Santa Fe: School of American Research Press.

Fash, William L., and Barbara Fash. 2005. "Teotihuacan and the Maya: A Classic Heritage." In Mesoamerica's Classic Heritage: From Teotihuacan to the Aztecs, edited by Davíd Carrasco, Lindsay Jones, and Scott Sessions, 433-63. Boulder: University Press of Colorado.

Fash, William L., and Kurt Z. Long. 1983. "E1 Mapa Arqueológico del Valle de Copán." In Introducción a la Arqueología de Copán, vol. 3, edited by Claude F. Baudez, I-48. Tegucigalpa, Honduras: Secretaria de Estado en el Despacho de Cultura y Turismo.

Fash, William L., and Robert J.Sharer. 1991. "Sociopolitical Developments and Methodological Issues at Copan, Honduras: A Conjunctive Perspective." Latin American Antiquity 2 (2): 166-87. http://dx.doi.org/ro.2307/972276.

Fash, William L., and David Stuart. 199r. "Dynastic History and Cultural Evolution at Copan, Honduras." In Classic Maya Political History, edited by T. Patrick Culbert, 147-79. School of American Research Advanced Seminar Series. Cambridge: University of Cambridge Press.

Ferguson, Yale H., and Richard W. Mansbach. 1996. Polities: Authority, Identities and Change. Columbia: University of South Carolina Press.

Fialko Coxemans, Vilma. I996. "Yaxha y Nakum: Jerarquías y Patrones de Asentamientos en sus Espacios Intersitios.” Mayab ıo: 15-24.

Foias, Antonia E. 1996. "Changing Ceramic Production and Exchange Systems and the Classic Maya Collapse in the Petexbatun Region.” PhD dissertation, Vanderbilt University, Nashville, TN.

Foias, Antonia E., and Kitty F. Emery, eds. 2012a. Motul de San José: Politics, History, and Economy in a Classic Maya Polity. Gainesville: University Press of Florida. http://dx.doi.org/10.5744/florida/978081304I902.001.000I. 
Foias, Antonia E., and Kitty F. Emery. 2012b. "Politics and Economics: Theoretical Perspectives of the Motul de San José Project.” In Motul de San José: Politics, History, and Economy in a Classic Maya Polity, edited by Antonia E. Foias and Kitty E. Emery, I-29. Gainesville: University Press of Florida. http://dx.doi.org/Io.5744 /florida/9780813041902.003.000I.

Foias, Antonia E., Christina T. Halperin, Ellen Spensley Moriarty, and Jeanette Castellanos. 20I2. "Architecture, Volumetrics, and Social Stratification at Motul de San José during the Late and Terminal Classic." In Motul de San José: Politics, History, and Economy in a Classic Maya Polity, edited by Antonia E. Foias and Kitty E. Emery, 94-I38. Gainesville: University Press of Florida. http://dx.doi.org/ıo .5744/florida/9780813041902.003.0004.

Folan, William J. 1992. "Calakmul, Campeche: A Centralized Urban Administrative Center in the Northern Peten.” World Archaeology 24 (I): 158-68. http://dx.doi.org/I o.1080/00438243.1992.9980199.

Folan, William J., Ellen R. Kintz, and Laraine A. Fletcher.1983. Cobá, a Classic Maya Metropolis. New York: Academic.

Ford, Anabel. 1986. Population Growth and Social Complexity. An Examination of Settlement and Environment in the Central Maya Lowlands. Anthropological Research Papers 35. Tempe: Arizona State University.

Foucault, Michel. 1983. "The Subject and Power." In Michel Foucault: Beyond Structuralism and Hermeneutics, 2 nd ed., edited by Hubert L. Dryfus and Paul Rabinow, 208-26. Chicago: University of Chicago Press.

Fox, John W., Garrett W. Cook, Arlen F. Chase, and Diane Z. Chase. 1996.

"Questions of Political and Economic Integration: Segmentary versus Centralized States among the Ancient Maya." Current Anthropology 37 (5): 795-801. http:// dx.doi.org/Io.1086/204563.

Freter, Ann Corine. r988. "The Classic Maya Collapse at Copan, Honduras: A Regional Settlement Perspective.” PhD dissertation, Pennsylvania State University, University Park.

Fry, Robert E. 1969. "Ceramics and Settlement in the Peripheries of Tikal, Guatemala." PhD dissertation, University of Arizona, Tucson.

Fry, Robert E. 2003. “The Peripheries of Tikal.” In Tikal: Dynasties, Foreigners, and Affairs of State, edited by Jeremy A. Sabloff, I43-70. Santa Fe: School of American Research Press.

Giddens, Anthony. 1979. Central Problems in Social Theory: Action, Structure and Contradictions in Social Analysis. Berkeley: University of California Press.

Giddens, Anthony. 1984. The Constitution of Society: Outline of a Theory of Structuration. Berkeley: University of California Press. 
Gifford, James C. 1976. Prehistoric Pottery Analysis and the Ceramics of Barton Ramie in the Belize Valley. Memoirs of the Peabody Museum of Archaeology and Ethnology vol. I8. Cambridge, MA: Harvard University.

Glatz, Claudia. 2009. "Empire as Network: Spheres of Material Interaction in Late Bronze Age Anatolia.” Journal of Anthropological Archaeology 28 (2): 127-4I. http:// dx.doi.org/Io.Ior6/j.jaa.2008.10.003.

Golden, Charles. 2oro. "Frayed at the Edges: Collective Memory and History on the Borders of Classic Maya Polities.” Ancient Mesoamerica 2I (2): 373-84. http://dx.doi .org/ıo.10i7/So956536110000246.

Hall, Jay, and René Viel. 2004. "The Early Classic Copan Landscape: A View from the Preclassic." In Understanding Early Classic Copan, edited by Ellen E. Bell, Marcello A. Canuto, and Robert J. Sharer, I7-28. Philadelphia: University of Pennsylvania Press.

Halperin, Christina T., and Antonia E. Foias. 20Io. "Pottery Politics: Late Classic Maya Palace Production at Motul de San José, Petén" Journal of Anthropological Archaeology 29 (3): 392-4Ir. http://dx.doi.org/Io.IoI6/j.jaa.20I0.06.oor.

Hammond, Norman. I99r. "Inside the Black Box: Defining Maya Polity.” In Classic Maya Political History: Hieroglyphic and Arcbaeological Evidence, edited by T. Patrick Culbert, 253-84. Cambridge: Cambridge University Press.

Hansen, Mogens H. 20ooa. "Conclusion." In A Comparative Study of Thirty CityState Cultures, edited by Mogens H. Hansen, 597-623. Copenhagen: Royal Danish Academy of Sciences and Letters.

Hansen, Mogens H. 20oob. "Introduction: The Concepts of City-State and CityState Culture." In A Comparative Study of Thirty City-State Cultures, edited by Mogens H. Hansen, II-34. Copenhagen: Royal Danish Academy of Sciences and Letters.

Hansen, Mogens H. 2006. Polis: An Introduction to the Ancient Greek City-State. Oxford: Oxford University Press.

Harrison, Peter D. 200o. The Lords of Tikal. London: Thames and Hudson. Haviland, William A. I963. "Excavation of Small Structures in the Northeast Quadrant of Tikal, Guatemala.” PhD dissertation, University of Pennsylvania, Philadelphia.

Haviland, William A. ı970. "Tikal, Guatemala and Mesoamerican Urbanism.” World Archaeology 2 (2): 186-98. http://dx.doi.org/ro.Io80/00438243.1970.9979473.

Haviland, William A. 198r. "Dower Houses and Minor Centers at Tikal, Guatemala: An Investigation into the Identification of Valid Units in Settlement Hierarchies." In Lowland Maya Settlement Patterns, edited by Wendy Ashmore, 89-I20. Albuquerque: School of American Research and University of New Mexico Press. 
Haviland, William A. 1985. Excavations in Small Residential Groups of Tikal: Groups ${ }_{4} F-I$ and $4 F-2$. Philadelphia: Museum of Archaeology and Anthropology, University of Pennsylvania.

Haviland, William A. 2003. "Settlement, Society, and Demography at Tikal." In Tikal: Dynasties, Foreigners, and Affairs of State, edited by Jeremy A. Sabloff, III-42. Santa Fe: School of American Research Press.

Healan, Dan M. 2009. "Household, Neighborhood, and Urban Structure in an 'Adobe City': Tula, Hidalgo, Mexico.” In Domestic Life in Prehispanic Capitals: A Study of Specialization, Hierarchy, and Ethnicity, edited by Linda R. Manzanilla and Claude Chapdelaine, 67-88. Memoirs of the Museum of Anthropology 46. Ann Arbor: University of Michigan.

Hendon, Julia A. I99r. "Status and Power in Classic Maya Society: An Archaeological Study." American Anthropologist 93 (4): 894-918. http://dx.doi.org/ro.I525/ aa.I991.93.4.02aooo7o.

Hendon, Julia A. 2009. "Maya Home Life: Daily Practice, Politics, and Society in Copan, Honduras." In Domestic Life in Prehispanic Capitals: A Study of Specialization, Hierarchy, and Ethnicity, edited by Linda R. Manzanilla and Claude Chapdelaine, I05-I29. Memoirs of the Museum of Anthropology 46. Ann Arbor: University of Michigan.

Hendon, Julia A. 2oro. Houses in a Landscape: Memory and Everyday Life in Mesoamerica. Durham, NC: Duke University Press.

Hicks, Frederic. 20I2. "Governing Smaller Communities in Aztec Mexico." Ancient Mesoamerica 23 (I): 47-56.http://dx.doi.org/Io.IoI7/So956536Ir200003X.

Hirth, Kenneth G. 1993. Households as an Analytical Unit: Problems in Method and Theory." In Prehispanic Domestic Units in Western Mesoamerica, edited by Robert S. Santley and Kenneth G. Hirth, 2I-36. Boca Raton, FL: CRC.

Hirth, Kenneth G, 2003. "The Altepel and Urban Structure in Prehispanic Mesoamerica.." In Urbanism in Mesoamerica, vol. r. edited by William T. Sanders, Alba Guadalupe Mastache, and Robert H. Cobean, 57-84. Mexico City: INAH. Hirth, Kenneth G. 2009. "Household, Workshop, Guild, and Barrio: The Organization of Obsidian Craft Production in a Prehispanic Urban Center.” In Domestic Life in Prehispanic Capitals: A Study of Specialization, Hierarchy, and Ethnicity, edited by Linda R. Manzanilla and Claude Chapdelaine, 43-65. Memoirs of the Museum of Anthropology 46. Ann Arbor: University of Michigan.

Houston, Stephen D., Héctor Escobedo, Mark Child, Charles W. Golden, and René Muñoz. 2003. "The Moral Community: Maya Settlement Transformation at Piedras Negras, Guatemala." In The Social Construction of Ancient Cities, edited by Monica L. Smith, 2I2-53. Washington, DC: Smithsonian Institution Press. 
Hutson, Scott R. 2010. Dwelling, Identity, and the Maya: Relational Archaeology at Chunchucmil. New York: AltaMira.

Iannone, Gyles. 2002. "Annales History and the Ancient Maya State: Some Observations on the 'Dynamic Model." American Anthropologist IO4 (I): 68-78. http://dx.doi.org/Io.1525/aa.2002.IO4.I.68.

Iannone, Gyles. 2006. "Archaeological Approaches to Ancient Maya Geopolitical Borders." In Space and Spatial Analysis in Archaeology, edited by Elizabeth Robertson, Jeffrey Seibert, Deepika Fernandez, and Marc Zender, 205-I4. Albuquerque: University of New Mexico Press.

Iannone, Gyles, and Samuel V. Connell, eds. 2003. Perspectives on Ancient Maya Rural Complexity. Cotsen Institute of Archaeology Monograph 49. Los Angeles: University of California.

Inomata, Takeshi. 20or. "The Power and Ideology of Artistic Creation: Elite Craft Specialists in Classic Maya Society." Current Anthropology 42 (3): 32I-49. http:// dx.doi.org/Io.1086/320475.

Inomata, Takeshi, and Kazuo Aoyama. 1996. "Central-Place Analyses in the La Entrada Region, Honduras: Implications for Understanding the Classic Maya Political and Economic Systems." Latin American Antiquity 7 (4): 29I-3I2. http:// dx.doi.org/Io.2307/972261.

Inomata, Takeshi, and Lawrence Cohen, eds. 2006. Archaeology of Performance: Theatres of Power, Community, and Politics. New York: AltaMira.

Inomata, Takeshi, and Stephen D. Houston. 200I. "Opening the Royal Maya Court." In Royal Courts of the Ancient Maya, vol. I, edited by Takeshi Inomata and Stephen D. Houston, 3-23. Boulder: Westview.

Inomata, Takeshi, and Daniela Triadan, eds. 20Io. Burned Palaces and Elite Residences of Aguateca: Excavations and Ceramics. Monographs of the Aguateca Archaeological Project First Phase, vol. I. Salt Lake City: University of Utah Press.

Insoll, Timothy. 2007. "Introduction: Configuring Identities in Archaeology." In The Archaeology of Identities: A Reader, edited by Timothy Insoll, I-I8. London: Routledge. Janusek, John W. 2008. Ancient Tiwanaku. Cambridge: Cambridge University Press. Jones, Grant D. 1986. “The Southern Maya Lowlands during Spanish Colonial Times.” In Handbook of Middle American Indians, Supplement 4: Ethnobistory, edited by Victoria R. Bricker and Ronald Spores, 7I-87. Austin: University of Texas Press. Jones, Grant D. 1998. The Conquest of the Last Maya Kingdom. Stanford: Stanford University Press.

Kantner,John. 2008. “The Archaeology of Regions: From Discrete Analytical Toolkit to Ubiquitous Spatial Perspective." Journal of Archaeological Research I6 (I): 37-8I. http://dx.doi.org/ro.I007/sio8I4-007-90I7-8. 
Knapp, A. Bernard, and Peter van Dommelen. 2008. "Past Practices: Rethinking Individuals and Agents in Archaeology." Cambridge Archaeological Journal I8 (I): 15-34. http://dx.doi.org/ro.IoI7/So95977430800oo24.

Kockelman, Paul. 2007. "Agency: The Relation between Meaning, Power, and Knowledge." Current Anthropology 48 (3): 375-40I. http://dx.doi. org/Io.1086/512998.

Kurjack, Edgar B. 1974. Prebistoric Lowland Maya Community and Social Organization. Middle American Research Institute Publication 38. New Orleans: Tulane University.

Laporte, Juan Pedro, and Héctor Mejía. 2005. La Organización Teritorial y Politica en el Mundo Maya Clásico: El Caso del Sureste y Centro-oeste de Petén, Guatemala. San Carlos, Guatemala: Instituto de Investigaciones Históricas, Antropológicas, Arqueológicas, Universidad de San Carlos de Guatemala.

Latour, Bruno. 2005. Reassembling the Social: An Introduction to Actor-NetworkTheory. Oxford: Oxford University Press.

LeCount, Lisa J., Jason Yaeger, Richard M. Leventhal, and Wendy Ashmore. 2002. "Dating the Rise and Fall of Xunantunich, Belize: A Late and Terminal Classic Lowland Maya Regional Center." Ancient Mesoamerica I3 (I): 4I-63. http:// dx.doi.org/Io.Ior7/So95653610213III7.

LeCount, Lisa J., and Jason Yaeger, eds. 2oroa. Classic Maya Provincial Politics: Xunantunich and Its Hinterlands. Tucson: University of Arizona Press.

LeCount, Lisa J., and Jason Yaeger. 2orob. "Provincial Politics and Current Models of the Maya State."In Classic Maya Provincial Politics: Xunantunich and Its Hinterlands, edited by Lisa J. LeCount and Jason Yaeger, 20-45. Tucson: University of Arizona Press, Tucson.

Lefebvre, Henri. 1991. The Production of Space. Oxford: Basil Blackwell.

Lemonnier, Eva. 2or2. "Neighborhoods in Classic Maya Lowland Societies: Their Identification and Definition from the La Joyanca Case Study." In The Neighborhood as a Social and Spatial Unit in Mesoamerican Cities, edited by M. Charlotte Arnauld, Linda R. Manzanilla, and Michael E. Smith, I8I-20I. Tucson: University of Arizona Press.

Liendo Stuardo, Rodrigo. 2003. The Organization of Agricultural Production at a Classic Maya Center: Settlement Patterns in the Palenque Region, Chiapas, Mexico. Pittsburgh: University of Pittsburgh Press.

Liendo Stuardo, Rodrigo. 20Ir. B'aakal: Arqueología de la Región de Palenque, Chiapas, México. BAR International Series, Paris Monographs in American Archaeology 26. Oxford: British Archaeological Reports.

Liu, Li, and Xingcan Chen. 2003. State Formation in Early China. London: Duckworth. 
Lohse, Jon C., and Fred Valdez Jr., eds. 2004. Ancient Maya Commoners. Austin: University of Texas Press.

Lucero, Lisa J. 2006. Water and Ritual: The Rise and Fall of Classic Maya Rulers. Austin: University of Texas Press.

Maca, Allan L. 2002. "Spatio-Temporal Boundaries in Classic Maya Settlement Systems: Copan's Urban Foothills and the Excavations at Group 9J-5." PhD thesis, Harvard University, Cambridge, MA.

Maca, Allan L. 2006. “Body, Boundaries, and 'Lived' Urban Space: A Research Model for the Eighth Century Maya City at Copan, Honduras." In Space and Spatial Analysis in Archaeology, edited by Elizabeth Robertson, Jeffrey Seibert, Deepika, Fernandez, and Marc Zender, I43-56. Albuquerque: University of New Mexico Press.

Mann, Michael. 1986. The Sources of Social Power, vol. I: A History of Power from the Beginning to $A D$ I760. Cambridge: Cambridge University Press.

Mann, Michael. 1993. The Sources of Social Power, vol. 2: The Rise of Classes and Nation States, I790-I9I4Cambridge: Cambridge University Press.

Manzanilla, Linda. 2009. "Corporate Life in Apartment and Barrios Compounds at Teotihuacan, Central Mexico: Craft Specialization, Hierarchy, and Ethnicity." In Domestic Life in Prehispanic Capitals: A Study of Specialization, Hierarchy, and Ethnicity, edited by Linda R. Manzanilla and Claude Chapdelaine, 2I-42. Memoirs of the Museum of Anthropology 46. Ann Arbor: University of Michigan.

Manzanilla, Linda R., and Claude Chapdelaine, eds. 2009. Domestic Life in Prehispanic Capitals: A Study of Specialization, Hierarchy, and Ethnicity. Memoirs of the Museum of Anthropology 46. Ann Arbor; University of Michigan.

Marcus, Joyce. 1983. "On the Nature of the Mesoamerican City." In Prehistoric Settlement Patterns, edited by Evon Z. Vogt and Richard L. Leventhal, I96-242. Albuquerque: University of New Mexico Press.

Marcus, Joyce. I993. “Ancient Maya Political Organization.” In Lowland Maya Civilization in the 8th Century AD, edited by Jeremy A. Sabloff and John S. Henderson, II-84. Washington, DC: Dumbarton Oaks Research Library and Collection.

Marcus, Joyce. 1998. "The Peaks and Valleys of Ancient States: An Extension of the Dynamic Model." In Archaic States, edited by Gary M. Feinman and Joyce Marcus, 59-94. Santa Fe: School of American Research Press.

Marcus, Joyce. 2004. "Primary and Secondary State Formation in Southern Mesoamerica." In Understanding Early Classic Copan, edited by Ellen E. Bell, Marcello A. Canuto, and Robert J. Sharer, 357-73. Philadelphia: University of Pennsylvania Press. 
Marken, Damien B. 20II. "City and State: Urbanism, Rural Settlement, and Polity in the Classic Maya Lowlands." PhD dissertation, Southern Methodist University, Dallas, TX.

Marken, Damien B., and Arnoldo González Cruz. 2007. "Elite Residential Compounds at Late Classic Palenque." In Palenque: Recent Investigations at the Classic Maya Center, edited by Damien B. Marken, I35-6o. New York: AltaMira.

Marken, Damien B., and Kirk D. Straight. 2007. "Conclusion: Reconceptualizing the Palenque Polity." In Palenque: Recent Investigations at the Classic Maya Center, edited by Damien B. Marken, 279-324. New York: AltaMira.

Martin, Simon, and Nikolai Grube. 1995. "Maya Superstates." Archaeology 48 (6): 4I-46.

Martin, Simon, and Nikolai Grube. 2000. Chronicles of the Maya Kings and Queens: Deciphering the Dynasties of the Ancient Maya. London: Thames and Hudson.

McBryde, Felix Webster. 1947. Cultural and Historical Geography of Southwest Guatemala. Publication 4. Washington, DC: Smithsonian Institution of Social Anthropology.

Moore, Jerry D. 2005. "Power and Practice in the Prehispanic Andes: Final Comments." In Foundations of Power in the Prehispanic Andes, edited by Kevin J. Vaughn, Dennis Ogburn, and Christina A. Conlee, 26r-74. Archaeological Papers I4. Arlington, VA: American Anthropological Association. http://dx.doi.org/Io.I525/ ap3a.2005.I4.26r.

Munson, Jessica L., and Martha J. Macri. 2009. "Sociopolitical Network Interaction: A Case Study of the Classic Maya." Journal of Anthropological Archaeology 28 (4): 424-38. http://dx.doi.org/Io.IOI6/j.jaa.2009.08.002.

Nelson, Zachary N. 2005. "Settlement and Population at Piedras Negras." PhD dissertation, Pennsylvania State University, University Park.

Oates, Joan. 1986. Babylon, rev. ed. London: Thames and Hudson.

Okoshi-Harada, Tsubasa. 20I2. "Postclassic Maya 'Barrios' in Yucatán: An Historical Approach." In The Neighborbood as a Social and Spatial Unit in Mesoamerican Cities, edited by M. Charlotte Arnauld, Linda R. Manzanilla, and Michael E. Smith, 286-30r. Tucson: University of Arizona Press.

Orrego Corzo, Miguel, and C. Rudy Larios. 1983. Tikal, Petén: Reporte de las Investigaciones Arqueológicas en el Grupo 5 E-II. Guatemala City: Parque Nacional Tikal, Instituto de Antropología e Historia.

Palka, Joel W. r997. "Reconstructing Classic Maya Socioeconomic Differentiation and the Collapse at Dos Pilas, Petén, Guatemala." Ancient Mesoamerica 8 (2): 293-306. http://dx.doi.org/Io.IoI7/So956536100001747.

Parkinson, William A. 2002. "Integration, Interaction, and Tribal 'Cycling': The Transition to the Copper Age on the Great Hungarian Plain.” In The Archaeology of 
Tribal Societies, edited by William A. Parkinson, 39I-438. Archaeology Series 15. Ann Arbor, MI: International Monographs in Prehistory.

Pauketat, Timothy R. 200I. "Practice and History in Archaeology: An Emerging Paradigm." Anthropological Theory I (I): 73-98. http://dx.doi.org/Io.II77/146349 90122228638.

Plank, Shannon E. 2004. Maya Dwellings in Hieroglyphs and Archaeology: An Integrative Approach to Ancient Architecture and Spatial Cognition. BAR International Series I324. Oxford: British Archaeological Reports.

Plunket, Patricia, ed. 2002. Domestic Ritual in Ancient Mesoamerica. Cotsen Institute of Archaeology Monograph 46. Los Angeles: University of California.

Prem, Hans. 1998. "Modelos de Entidades Políticas: Una Síntesis.” In Modelos de Entidades Politicas Mayas, edited by Silvia Trejo, 27-34. Mexico City; Instituto Nacional de Antropología e Historia.

Puleston, Dennis E. 1973. "Ancient Maya Settlement Patterns and Environment at Tikal, Guatemala: Implications for Subsistence Models.” $\mathrm{PhD}$ dissertation, University of Pennsylvania, Philadelphia.

Puleston, Dennis E. 1983. The Settlement Survey of Tikal. Tikal Report I3, Monograph 48. Philadelphia: University Museum, University of Pennsylvania. http://dx.doi.org /10.9783/9781934536353.

Puleston, Dennis E., and Donald W. Callender Jr. 196\%. "Defensive Earthworks at Tikal." Expedition 9 (30): 40-48.

Pyburn, K. Anne. 2008. "Pomp and Circumstance before Belize: Ancient Maya Commerce and the New River Conurbation." In The Ancient City, edited by Joyce Marcus and Jeremy A.Sabloff, 247-72. Santa Fe: School of American Research Press.

Rappaport, Amos. 1988. "Levels of Meaning in the Built Environment." In CrossCultural Perspectives in Non-Verbal Communication, edited by Fernando Poyatos, 317-36. Toronto: C.J. Hogrefe.

Renfrew, Colin. I986. "Introduction: Peer Polity Interaction and Socio-Political Change." In Peer Polity Interaction and Socio-Political Change, edited by Colin Renfrew and John F. Cherry, I-I8. Cambridge: Cambridge University Press.

Robin, Cynthia. 1999. "Towards an Archaeology of Everyday Life: Maya Farmers of Chan Noohol and Dos Chombitos Cikin, Belize." PhD dissertation, University of Pennsylvania, Philadelphia.

Robin, Cynthia. 2002. "Outside of Houses: The Practices of Everyday Life at Chan Nóohol, Belize.” Journal of Social Archaeology 2 (2): 245-68.

Robin, Cynthia. 2003. "New Directions in Classic Maya Household Archaeology." Journal of Archaeological Research II (4): 307-56. http://dx.doi.org/Io.I023/A :1026327105877. 
Robin, Cynthia. 2006. "Gender, Farming, and Long-Term Change: Maya Historical and Archaeological Perspectives." Current Anthropology 47 (3): 409-33. http:// dx.doi.org/1o.1086/503060.

Robin, Cynthia, ed. 20I2. Chan: An Ancient Maya Farming Community. Gainesville: University Press of Florida. http://dx.doi.org/Io.5744/florida/978081303983I .oor.ooor.

Robin, Cynthia, Jason Yaeger, and Wendy Ashmore. 20I0. "Living in the Hinterlands of a Provincial Polity." In Classic Maya Provincial Politics: Xunantunich and Its Hinterlands, edited by Lisa J. LeCount and Jason Yaeger, 315-33. Tucson: University of Arizona Press.

Roys, Ralph. 1957. The Political Geography of the Yucatan Maya. Publication 6r3. Washington, DC: Carnegie Institution of Washington.

Sabloff, Jeremy A. I986. "Interaction among Classic Maya Polities: A Preliminary Examination." In Peer Polity Interaction and Socio-Political Change, edited by Colin Renfrew and John F. Cherry, Io9-I6. Cambridge: Cambridge University Press.

Sabloff, Jeremy A. 1994. The Nerw Archaeology and the Ancient Maya. New York: Scientific American Library.

Sabloff, Jeremy A., ed. 2003. Tikal: Dynasties, Foreigners, and Affairs of State. Santa Fe: School of American Research Press.

Saitta, Dean. 1994. "Agency, Class, and Archaeological Interpretation.” Journal of Anthropological Archaeology I3 (3): 20I-27. http://dx.doi.org/Io.Ioo6/jaar.I994.IoI3.

Sanders, William T., and Barbara J. Price. 1968. Mesoamerica: The Evolution of a Civilization. New York: Random House.

Sanders, William T., and David Webster. 1988. "The Mesoamerican Urban Tradition.” American Anthropologist 90 (3):521-46. http://dx.doi.org/Io.1525/aa.I988.90.3 .02aoooio.

Santley, Robert S., and Kenneth G. Hirth, eds. 1993. Prehispanic Domestic Units in Western Mesoamerica. Boca Raton, FL: CRC.

Scarborough, Vernon L., and Fred Valdez Jr. 2003. "The Engineered Environment and Political Economy of the Three Rivers Area." In Heterarchy, Political Eonomy, and the Ancient Maya, edited by Vernon L. Scarborough, Fred Valdez Jr., and Nicholas Dunning, 3-13. Tucson: University of Arizona Press.

Scarborough, Vernon L., Fred Valdez Jr., and Nicholas Dunning, eds. 2003. Heterarchy, Political Economy, and the Ancient Maya. Tucson: University of Arizona Press.

Scherer, Andrew K., and Charles Golden. 2009. "Tecolote, Guatemala: Archaeological Evidence for a Fortified Late Classic Maya Political Border.” Journal of Field Archaeology 34 (3): 285-305. http://dx.doi.org/Io.II79/0093469 09791070907. 
Schortman, Edward M. 1989. "Interregional Interaction in Prehistory: The Need for a New Perspective." American Antiquity 54 (I): 52-65. http://dx.doi.org/Io.2307/28I33I. Schortman, Edward M., and Wendy Ashmore. 20I2. "History, Networks, and the Quest for Power: Ancient Political Competition in the Lower Motagua Valley, Guatemala." Journal of the Royal Anthropological Institute I8 (I): I-2I. http://dx.doi .org/IO.IIII/j.I467-9655.2011.01728.x.

Schortman, Edward M., and Patricia A. Urban. 2012. "Enacting Power through Networks." Journal of Anthropological Archaeology 3I (4): 500-5I4. http://dx.doi.org /Io.IoI6/j.jaa.20I2.04.00I.

Schortman, Edward M., Patricia A. Urban, and Marne Ausec. 20or. "Politics with Style: Identity Formation in Prehispanic Southeastern Mesoamerica." American Anthropologist IO3 (2): 312-30. http://dx.doi.org/IO.I525/aa.200I.IO3.2.3I2.

Sharer, Robert J. 1988. “Quirigua as a Classic Maya Center.” In The Southeast Classic Maya Zone, edited by Elizabeth H. Boone and Gordon R. Willey, 35-65. Washington, DC: Dumbarton Oaks Research Library and Collection.

Sharer, Robert J. I993. "The Social Organization of the Late Classic Maya: Problems of Definition and Approaches." In Lowland Maya Civilization in the 8th Century $A D$, edited by Jeremy A. Sabloff and John S. Henderson, 91-Iog. Washington, DC: Dumbarton Oaks Research Library and Collection.

Sharer, Robert J., and Charles W. Golden. 2004. "Kingship and Polity: Conceptualizing the Maya Body Politic." In Continuities and Changes in Maya Archaeology:

Perspectives at the Millennium, edited by Charles W. Golden and Greg Borgstede, 23-50. New York: Routledge.

Sharer, Robert J., with Loa Traxler. 2006. The Ancient Maya, 6th ed. Palo Alto, CA: Stanford University Press.

Smith, Adam T. 2003a. The Political Landscape: Constellations of Authority in Early Complex Society. Berkeley: University of California Press.

Smith, Michael E. 2008. Aztec City-State Capitals. Gainesville: University Press of Florida. Smith, Michael E. 2oro. "The Archaeological Study of Neighborhoods and Districts in Ancient Cities," Journal of Anthropological Archaeology 29 (2): 137-54. http://dx.doi.org /Io.IoI6/j.jaa.20Io.oI.oor.

Smith, Michael E. 20II. "Classic Maya Settlement Clusters as Urban Neighborhoods: A Comparative Perspective on Low-Density Urbanism.” Journal de la Société des Americanistes 97-I: 5 $^{\mathrm{I}}-73$.

Smith, Michael E., and Juliana Novic. 2012. "Introduction: Neighborhoods and Districts in Ancient Mesoamerica." In The Neighborhood as a Social and Spatial Unit in Mesoamerican Cities, edited by M. Charlotte Arnauld, Linda R. Manzanilla, and Michael E. Smith, I-26. Tucson: University of Arizona Press. 
Smith, Monica L. 2003b. "Introduction: The Social Construction of Ancient Cities." In The Social Construction of Ancient Cities, edited by Monica L. Smith, I-36. Washington, DC: Smithsonian Books.

Smith, Monica L. 2005. "Networks, Territories, and the Cartography of Ancient States." Annals of the Association of American Geographers 95 (4): 832-49. http://dx.doi.org /I0.IIII/j.I467-8306.2005.00489.x.

Stein, Gil J. 2002. "From Passive Periphery to Active Agents: Emerging Perspectives in the Archaeology of Interregional Interaction." American Anthropologist Io4 (3): 903-I6. http://dx.doi.org/Io.I525/aa.2002.I04.3.903.

Straight, Kirk D. 2012. "Consumption of Pottery and Lithics in the Peripheries of Tikal, Guatemala." PhD dissertation, Pennsylvania State University, University Park.

Stuart, David, and Stephen D. Houston. 1994. Classic Maya Place Names. Washington, DC: Dumbarton Oaks Research Library and Collection.

Tambiah, Stanley J. I977. "The Galactic Polity: The Structure of Traditional Kingdoms in Southeast Asia." In Anthropology and the Climate of Opinion, edited by Stanley A. Freed, 69-97. Annals of the New York Academy of Science 293. New York: New York Academy of Science.

Tokovinine, Alexandre. 20I3. Place and Identity in Classic Maya Narratives. Washington, DC: Dumbarton Oaks Research Library and Collection.

Tourtellot, Gair. 1988. Excavations at Seibal, Part 4: Peripheral Survey and Excavation: Settlement and Community Patterns. Memoirs of the Peabody Museum i6. Cambridge, MA: Harvard University.

Tozzer, Alfred. I94I. Landa's Relación de las Cosas de Yucatán. Papers of the Peabody Museum of Archaeology and Ethnology I8. Cambridge, MA: Harvard University.

Vogt, Evon Z. 1969. Zinacantan: A Maya Community in the Highlands of Chiapas.

Cambridge, MA:Harvard University Press. http://dx.doi.org/ro.4I59/ harvard.9780674436886.

Webster, David, 2005. "Political Ecology, Political Economy, and the Culture History of Resource Management at Copán." In Copán: Rise and Fall of a Classic Maya Kingdom, edited by E. Wyllys Andrews V and William L. Fash, 33-72. Santa Fe: School of American Research Press.

Webster, David, and Nancy Gonlin. r988. "Household Remains of the Humblest Maya." Journal of Field Archaeology I5 (2): 169-90. http://dx.doi.org/Io.II79/oo934698879I 974484 .

Webster, David, Timothy M. Murtha, Kirk D. Straight, Jay Silverstein, Horacio Martínez, Richard E. Terry, and Richard Burnett. 2007. "The Great Tikal Earthwork Revisited.” Journal of Field Archaeology 32 (I): 4I-64. http://dx.doi.org/Io.II79 /oo9346907791071700. 
Webster, David, and William T. Sanders. 20or. "La Antigua Ciudad Mesoamericana: Teoría y Concepto.” In Reconstruyendo la Cuidad Maya: El Urbanismo en Las Sociedades Antiguas, edited by Andreas Cuidad Ruiz, M. Josefa Iglesias Ponce De León, and M. Carmen Martínez Martínez, 34-64. Publication 6. Madrid: Sociedad Española de Estudios Mayas.

Webster, David, Jay Silverstein, Timothy Murtha, Horacio Martínez, and Kirk Straight. 2004. The Tikal Earthworks Revisited. Occasional Paper in Anthropology 28. University Park: Pennsylvania State University.

Wilk, Richard R., and Wendy Ashmore, eds. I988. Household and Community in the Mesoamerican Past. Albuquerque: University of New Mexico Press.

Wilk, Richard R., and Robert McC. Netting. r984. "Households: Changing Forms and Functions." In Households: Comparative and Historical Studies of the Domestic Group, edited by Robert McC. Netting, Richard R. Wilk, and Eric J. Arnould, I-28. Berkeley: University of California Press.

Willey, Gordon R., and William R. Bullard Jr. 1965. "Prehistoric Settlement Patterns in the Maya Lowlands." In Handbook of Middle American Indians, vol. 2: Archaeology of Southern Mesoamerica, Part 2, edited by Gordon R. Willey, 360-77. Austin: University of Texas Press.

Willey, Gordon R., William R. Bullard Jr., John B. Glass, and James C. Gifford. 1965. Prehistoric Settlement in the Belize Valley. Papers of the Peabody Museum of Archaeology and Ethnology vol. 54. Cambridge, MA: Harvard University.

Willey, Gordon R., and Richard M. Leventhal. r979. "Prehistoric Settlement at Copán." In Maya Archaeology and Ethnohistory, edited by Norman Hammond and Gordon R. Willey, 75-Io2. Austin: University of Texas Press.

Willey, Gordon R., Ledyard Smith, Gair Tourtellot III, and Ian Graham. I975. Excavations at Seibal, Number 1: Introduction to the Site and Its Setting. Memoirs of the Peabody Museum I3. Cambridge, MA: Harvard University.

Wolf, Eric R. 1990 "Distinguished Lecture: Facing Power-Old Insights, New Questions." American Anthropologist 92 (3): 586-96. http://dx.doi.org/Io.I525/ aa.1990.92.3.02a00020.

Wolf, Eric R. 1999. Envisioning Power: Ideologies of Dominance and Crisis. Berkeley: University of California Press.

Wolf, Eric R. 200I [1957]. Pathways of Power: Building an Anthropology of the Modern World. Berkeley: University of California Press. http://dx.doi.org/Io.I525/ california/9780520223332.00I.000I.

Yaeger, Jason. 200oa. "Changing Patterns of Social Organization: The Late and Terminal Classic Communities at San Lorenzo, Cayo District, Belize." PhD dissertation, University of Pennsylvania, Philadelphia. 
Yaeger, Jason. 200ob. "The Social Construction of Communities in the Classic Maya Countryside: Strategies of Affiliation in Western Belize." In The Archaeology of Communities: A New World Perspective, edited by Marcello A. Canuto and Jason Yaeger, I23-42. London: Routledge.

Yaeger, Jason. 2003. "Untangling the Ties That Bind.” In The Social Construction of Ancient Cities, edited by Monica Smith, I2I-55. Washington, DC: Smithsonian Institution Press.

Yaeger, Jason, and Marcello A. Canuto. 2000. "Introducing an Archaeology of Communities." In The Archaeology of Communities: A New World Perspective, edited by Marcello A. Canuto and Jason Yaeger, I-I5. London: Routledge.

Yoffee, Norman. I988. "The Collapse of Ancient Mesopotamian States and Civilizations." In The Collapse of Ancient States and Civilizations, edited by Norman Yoffee and George L. Cowgill, 44-68. Tucson: University of Arizona Press.

Yoffee, Norman. 2005. Myths of the Archaic State. Cambridge: Cambridge University Press. http://dx.doi.org/ıo.IoI7/CBO97805II489662.

York, Abigail M., Michael E. Smith, Benjamin W. Stanley, Barbara L. Stark, Juliana Novic, Sharon L. Harlan, George L. Cowgill, and Christopher G. Boone. 201 . "Ethnic and Class Clustering through the Ages: A Transdisciplinary Approach to Urban Neighborhood Social Patterns." Urban Studies 48 (II): 2399-4I5. http:// dx.doi.org/10.II77/0042098010384517. 